\title{
HASIL BELAJAR KETERAMPILAN BERMAIN BULUTANGKIS STUDI EKSPERIMEN PADA SISWA DIKLAT BULUTANGKIS FPOK-UPI
}

\author{
Herman Subarjah \\ FPOKUniversitas Pendidikan Indonesia (email: herman_subarjah@yahoo.co.id)
}

\begin{abstract}
Effects of Learning Models on Badminton Learning Achievement. This study aims to find out the effects of the tactical approach and the conventional approach on the badminton learning achievement. The experiment was conducted in the Bandung Badminton Club of FPOK UPI. The results of the study were as follows. First, in general, the skills of female badminton players using the tactical approach are better than those of the players using the conventional approach. Second, the skills of female players with high motor ability using the tactical approach are better than those of the players using the conventional approach. Third, the skills of female players with low motor ability using the tactical approach are not significantly different from those of the players using the conventional approach. Fourth, there is an interaction between the teaching models and motor ability in relation to the female players' badminton skills.
\end{abstract}

Keywords : tactical approach, conventional approach, badminton learning achievement

\section{PENDAHULUAN}

Permainan bulutangkis merupakan salah satu cabang olahraga permainan yang populer dan banyak digemari masyarakat di Indonesia, bahkan di seluruh dunia. Permainan ini menggunakan raket sebagai alat pemukul dan satelkok sebagai objek pukul, dapat dimainkan di lapangan tertutup maupun terbuka. Lapangan permainan berbentuk empat persegi panjang yang ditandai dengan garis, dibatasi oleh net untuk memisahkan antara daerah permainan sendiri danpermainanlawan. Permainan ini bersifat individual, dapat dimainkan satu orang lawan satu orang atau dua orang lawan dua orang. Dapat dimainkan oleh putera, puteri, dapat pula dimainkan oleh pasangan campuran putera dan puteri.
Bulutangkis merupakan permainan yang banyak menggunakan kemampuan fisik dengan gerakan yang cepat dan pukulan keras yang dilakukan dalam waktu beberapa detik di antara reli-reli panjang (Ballou, 1998). Keterampilan dasar yang diperlukan dalam bulutangkis di antaranya adalah cara memegang raket, sikap berdiri, gerakan kaki, dan memukul satelkok (Grice, 1994; Davis, 1998; Djide, 2000). Dalam kaitannya dengan keterampilan dasar memukul satelkok, seseorang sudah dapat bermain bulutangkis apabila dapat melakukan beberapa keterampilan dasar teknik memukul satelkok, yang terdiri atas servis, lob, drive, netting, dropshot, dan smash (Wattanasin, 2000; Han Jian, 2000; Grice, 1994). Keempat jenis keterampilan dasar teknik memukul satelkok tersebut 
dapat dilakukan dengan forehand maupun backhand.

Berdasarkan pengamatandalam proses pembelajaran bulutangkis pada beberapaperkumpulan, ditemukan dua kecenderungan penggunaan model pembelajaran, yaitu model pendekatan pembelajaran yang menekankan pada penguasaanteknik dasar (pendekatan konvensional) dan model pendekatan yang menekankan pada usaha untuk meningkatkan kemampuan bermain bulutangkis (pendekatan taktis). Pendekatan konvensional merupakan salah satu model pendekatan yang menekankan pada pembelajaranketerampilan teknis, mengutamakanpenguasaan keterampilan teknik dasar. Pendekatan ini mengutamakan proses pembelajaran untuk mencapai tujuan dan menjadi target sasaran yang diharapkan. Bagaimana keterampilan gerak dalam bulutangkis dapat dimainkan dengan mengkonsentrasikan pada unsur-unsur yang lebih spesifik dan terpisah dari keterampilan tersebut. Meskipun model pembelajaran pendekatan konvensional dapat meningkatkan keterampilan teknik dasar, hal ini ternyata banyak mendapatkan kritikan, salah satunya dikemukakan oleh Griffin (1997), yaitu keterampilan yang diajarkan sebelum siswa mengerti keterkaitannya dengan situasi bermain bulutangkis yang sesungguhnya. Hasilnya dapat menghilangkan esensi dari permainan bulutangkis itu sendiri.

Pendekatan taktis dimaksudkan untuk mendorong atlet dalam upaya memecahkan masalah taktik dalam permainan bulutangkis. Masalah ini pada hakikatnya berkenaan dengan penerapan beberapa keterampilan teknik dalam situasi permainan. Diharapkan siswa dapat memahami kaitan antara teknik dan taktik bermain bulutangkis. Pembelajaran melalui pendekatan taktis lebih menekankan terhadap bagaimana membelajarkan siswa untuk dapat memahami konsep bermain bulutangkis. Pendekatan taktis dalam permainan bulutangkis disesuaikan dengan kebutuhan untuk meningkatkan mutu pembelajaran bulutangkis.

Belajar adalah proses yang mengantarkan ke arah perubahan perilaku (kognitif, afektif, psikomotor), relatif menetap sebagai akibat dari proses latihan atau pengalaman dan bukan karena pengaruh kondisi tubuh yang bersifat temporer, seperti yang disebabkan oleh sakit, kelelahan atau obat-obatan. Hasil belajar adalah tingkat kemampuan penguasaan siswa terhadap tujuan belajar yang ditetapkan (Burden dan Byrd, 1999). Salah satu jenis belajar yang terkait dengan aktivitas olahraga disebut belajar keterampilan gerak.

Belajar keterampilan gerak adalah seperangkat proses internal yang berhubungan dengan latihan (pengalaman) yang menghasilkan perubahan-perubahan tingkah laku yang relatif permanen dalam bentuk perilaku gerak yang terampil (Schmidt, 1991; Fischman dan Oxendine, 1993). Sesuai definisi ini, ada tiga ciri pokok untuk memahami belajar keterampilan gerak. Pertama, belajar keterampilan gerak merupakan seperangkat proses internal yang berhubungan dengan aktivitas pemberian latihan (pengalaman). Proses pembelajaran atau pengalaman adalah proses yang sengaja diciptakan dengan tujuan untuk menguasai pengetahuan dan keterampilan baru. Kedua, karena sifatnya internal, 
belajar keterampilan gerak tidak secara langsung dapat diamati. Ketika proses berlangsung, sistem memori otak menerima sejumlah input berupa kemampuan dan pengalaman gerak, input tersebut diproses, diorganisasi, dandiubah menjadi pola gerak otot-otot, proses perubahan tersebut berlangsung tanpa bisa diamati secara langsung, kecuali hanya bisa ditafsirkan eksistensinya dari perubahan-perubahan yang terjadi melalui gerak. Ketiga, perubahan perilaku yang terjadi relatif permanen. Siswa dianggap belajar jika perubahan yang dialami bersifat relatif permanen, hasil belajar yang diperoleh dapat bertahan relatif lama. Sebaliknya, tidak dianggap belajar jika perubahan yang dialami bersifat sementara dan timbul akibat proses kematangan fisik, faktor kelelahan, sakit, atau obat. Hanya melalui pembelajaran dan pengalaman perubahan yang relatif permanen akan tercapai, maka pembelajaran dan pengalaman menjadi sesuatu yang penting dalam upaya memperoleh hasil yang diharapkan. Berdasarkan uraian di atas, belajar keterampilan gerak dapat diartikan sebagai seperangkat proses internal yang mengantarkan ke arah perubahan perilaku, terutama perilaku gerak yang relatif permanen sebagai akibat dari proses latihan (pengalaman) dan bukan karena pengaruh kondisi tubuh yang bersifat sementara, seperti pengaruh obatobatan atau proses kematangan fisik.

Istilah keterampilan biasanya digunakan untuk menggambarkan tingkat kemampuan seseorang untuk menyelesaikan tugas. Keterampilan adalah derajat keberhasilan dalam mencapai tujuan dengan efektif dan efisien (Singer,
1980). Keterampilan diartikan pula sebagai kemampuan prosedural tentang cara menampilkan suatu tugas gerak tertentu yang terentang dari tingkat yangpaling sederhana sampai paling kompleks (Anderson, 1995). Keterampilan dalam kedua pengertian ini secara implisit menunjuk kepada suatu tugas atau perbuatan tertentu dan menjadi indikator dari suatu tingkat kemahiran dalam kaitannya dengan pencapaian tujuan. Dalam fungsinya sebagai indikator dari suatu tingkat kemahiran, keterampilan dikonsepsikan sebagai kompetensi yang diperagakan oleh seseorang dalam melakukan suatu tugas yang berkaitan dengan pencapaian suatu tujuan.

Hasil belajar didefinisikan sebagai tingkat performa (penguasaan) siswa terhadap tujuan belajar dalam jangka waktu tertentu. Hasil belajar dalam konteks belajar keterampilan gerak dapat diartikan sebagai tingkat kemampuan penguasaan terhadap tujuan belajar keterampilan gerak yang dapat diukur melalui tes tertentu. Dengan demikian, hasil belajar keterampilan bermain bulutangkis adalah tingkat performa keterampilan bermain pemain bulutangkis yang diperoleh melalui proses pengukuran sesuai dengan jenis keterampilan yang dipelajarinya.

\section{MODEL PEMBELAJARAN}

Model pembelajaran merupakan rencana atau pola yang dapat digunakan untuk menyusun materi pembelajaran dan berguna sebagai pedoman pembelajaran. Model pembelajaran didesain untuk mencapai tujuan pembelajaran. Model pembelajaran yaitu suatu kerangka konseptual mengenai inter- 
aksi belajar mengajar yang disusun secara sistematis dan dirancang serta dikembangkan untuk membantu tercapainya tujuan pembelajaran. Model pembelajaran merupakan salah satu faktor penting dalam upaya meningkatkan kualitas proses pembelajaran yang sekaligus diharapkan dapat meningkatkan hasil belajar siswa.

\section{MODEL PEMBELAJARAN PENDE- KATAN TAKTIS}

Model pembelajaran pendekatan taktis dijelaskan oleh Griffin, Mitchell dan Oslin (1997), bahwa dengan menggunakan pendekatan taktis adalah model pembelajaran yang bertujuan meningkatkan kemampuan anak dalam olahraga permainan yang didukung oleh pemahaman terhadap taktik dan penguasaan keterampilan. Selanjutnya, Oslin (1996) menyatakan bahwa pendekatan taktis digunakan untuk mengubah cara guru mengajar permainan dengan penekanan pada pengembangan penalaran anak. Mitchell (1996) menyatakan bahwa pendekatan taktis diarahkan untuk meningkatkan kemampuan bermain dengan memadukan keterampilan teknik dan pemahaman taktik, dan pendorong agar siswa dapat menghargai nilai-nilai keterampilan dalam konteks permainan. Dari pendapat tersebut, dapat dikatakan bahwa model pembelajaran dengan pendekatan taktis merupakan model pembelajaran yang menggunakan masalah-masalah taktik dengan tingkat kesulitan tertentu dan digunakan sebagai alat untuk mencapai tujuan pembelajaran, yaitu meningkatkan kemampuan anak dalam olahraga permainan yang didukung oleh pema- haman taktik dan penguasaan keterampilan bermain.

Berdasarkan pendapat tersebut dapat dikemukakan bahwa model pembelajaran pendekatan taktis adalah usaha yang terencana untuk menyempurnakan penampilan permainan yang di dalamnya terkandung penggabungan unsur kesadaran taktis dan pelaksanaan beberapa keterampilan. Model pembelajaran ini yang bertujuan untuk meningkatkan kesadaran atlet terhadap konsep bermain bulutangkis sesuai dengan situasi permainan bulutangkis.

\section{MODEL PEMBELAJARAN PENDE- KATAN KONVENSIONAL}

Model pembelajaran dengan pendekatan konvensional merupakan model yang saat ini banyak digunakan oleh guru dan pembina olahraga, baik di sekolah maupun di perkumpulan olahraga. Hal ini karena adanya pandangan bahwa untuk dapat memainkan suatu keterampilan olahraga permainan, mutlak diperlukan penguasaan teknik dasar yang akan mendukung penampilan dalam olahraga permainan tanpa memandang kepada siapa permainan tersebut diajarkan dan sesuaikah suatu model digunakan. Menurut Dick (1989) pendekatan ini menekankan pada keterampilan teknis dengan proses kegiatan latihan aktivitas fisik yang dilaksanakan secara bertahap untuk mengkoordinasikan pola-pola gerak dasar menjadi satu kesatuan.

Pendekatan konvensional sering disebut juga dengan pendekatan tradisional, yaitu lebih berorientasi pada pencapaian keterampilan teknik bermain, proses pembelajaran dengan pendekat- 
an konvensional biasanya diawali dengan guru memberi contoh suatu gerakan keterampilan. Kemudian, siswa meniru atau melakukan gerakan tersebut, dan melakukan secara berulangulang. Dalam pelaksanaannya siswa menunggu perintah guru untuk melaksanakan tugas gerak yang diinstruksikan, sehingga sering disebut dengan gaya komando. Model pendekatan ini umumnya dilakukan pada klub bulutangkis. Pendekatan ini menekankan pada keterampilan teknis dengan proses kegiatan latihan aktivitas fisik yang dilaksanakan secara bertahap untuk mengkoordinasikan pola-pola gerak dasar menjadi satu kesatuan. Dengandemikian, model pembelajaran dengan pendekatan konvensional adalah suatu kerangka konseptual mengenai interaksi belajar mengajar yang disusun secara sistematis dan dirancang serta dikembangkan menggunakan pendekatan penguasaan teknik yang mengutamakan keterampilan teknis melalui pengulangan pola gerak dasar sebagai alat untuk mencapai tujuan pembelajaran, yaitu penguasaan keterampilan bermain bulutangkis.

\section{KEMAMPUAN MOTORIK}

Pada dasarnya setiap orang memiliki kemampuan motorik yang berbeda satu sama lainnya. Kemampuan motorik merupakan karakteristik kemampuan yang melekat pada diri seseorang. Menurut Wall dan Murray (1994), yang dimaksud dengan kemampuan motorik adalah kapasitas penampilan seseorang dalam melakukan tugas gerak. Menurut Oxendine (1968), kemampuan motorik adalah gambaran dari salah satu kecakapan dalam melakukan bermacam- macam keterampilan dasar dan aktivitas fisik secarakeseluruhan. Selanjutnya, Seidel (1975) mengutip pendapat Singer bahwa kemampuan motorik diindikasikan sebagai penampilan kemampuan olahraga yang dimiliki oleh seseorang secara individu yang berguna sebagai landasan untukmelakukan berbagai macam gerak keterampilan motorik. Di sisi lain,Oxendine(1968) memaknai kemampuan motorik sebagai gambaran dari salah satu kecakapan dalam melakukan berbagai macam keterampilan dasar dan aktivitas fisik secara keseluruhan.

Berdasarkan ilustrasi singkat di atas, dapat disimpulkan bahwa kemampuan motorik adalah kemampuan bawaan dan kemampuan yang dapat dipelajari yang mendasari penampilan sejumlah keterampilan gerak dan aktivitas fisik secara keseluruhan. Meskipun faktor bawaan dan lingkungan samasama berpengaruh, tetapi faktor bawaan dianggap sebagai kekuatan utama yang mempengaruhikemampuan motorik. Ada delapan aspek kemampuan motorik, di antaranya yaitu kekuatan otot, daya tahan otot dan kardiovaskuler, kecepatan, kelincahan, keseimbangan, power otot, koordinasi mata-tangan dan mata-kaki. Lebih lanjut Singer (1980) menyebutkan ada empat komponen yang berhubungan secara langsung dan mempengaruhi kemampuan motorik, yaitu kemampuan koordinasi, keseimbangan, kecepatan gerak, dan kinestetik.

Untuk mengetahui kemampuan motorik siswa, dilakukan pengukuran. Sesuai dengan karakteristik subjek penelitian, jenis tes yang digunakan adalah tes kemampuan motorik untuk usia anak sekolah dasar yang dikembangkan oleh 
Arnheim dan Sinclair (Kirkendal, 1980). Tesiniditujukan untuk mengukur kemampuansiswa dalam menampilkan kemampuan motorik dan aktivitas fisik secara keseluruhan yang didapat dari pengalaman gerak pada masa anak-anak. Tes kemampuan motorik untuk anak, terdiri dari tujuh item, yakni: (a) melempar pada sasaran atu target (target throwing); (b) Kelentukan togok dan tungkai (back and hamstring stretch); (c) melompat jauh ke depan tanpa awalan (standing long jump); (d) telungkup langsung bangun (face down to standing); (e) push-up pada kursi (chair push-up); (f) keseimbangan status (static balance); (g) kelincahan lari (agility run).

Berdasarkan uraian tersebut, penelitian ini difokuskan pada pengaruh model pembelajaran antara siswa yang menggunakan model pendekatan taktis dan pendekatan konvensional dengan memperhatikan kemampuan motorik siswa, serta interaksi antara keduanya terhadap hasil belajar keterampilan bermain bulutangkis siswa pemula puteri pada Diklat Bulutangkis FPOK UPI. Diduga (1) terdapat perbedaan hasil belajar keterampilan bermain bulutangkis antara siswa yang menggunakan model pendekatan taktis dengan yang menggunakan model pendekatan teknis secara keseluruhan; (2) terdapat perbedaan hasil belajar keterampilan bermain bulutangkis antara siswa yang menggunakan model pendekatan taktis dengan yang menggunakan pendekatan konvensional, dalam hal ini hasil belajar keterampilan bermain bulutangkis dengan menggunakan model pendekatan taktis lebih baik daripada model pendekatan konvensional pada siswa pemula puteri yang memiliki memampuan motorik tinggi;(3) siswa yangmenggunakan pendekatan konvensional lebih tinggi hasilnya dari pada siswa yang menggunakan pendekatan taktis; (4) terdapat interaksi antara model pembelajaran dengan kemampuan motorik terhadap hasil belajar keterampilan bermain bulutangkis pada siswa pemula.

\section{METODE}

Metode yang digunakan dalam penelitian ini ialah eksperimen. Metode eksperimen merupakan metode penelitian yang dapat dengan benar menguji hipotesis mengenai hubungan sebab akibat. Rancangan penelitian yang dipakai adalah desain faktorial $2 \times 2$. Peneliti dengan sengaja dan secara sistematis memberikan perlakuan untuk kemudian mengamati pengaruh dari perlakuan tersebut, baik dalam bentuk simple effect, main effect, maupun interaction effect.

\section{PROSEDUR}

Penelitian dilakukan terhadap siswa pemula puteri anggota diklat bulutangkis FPOK UPI di Bandung Propinsi Jawa Barat. Pelaksanaan penelitian dilakukan di Sporthall FPOK UPI selama dua setengah bulan (10 minggu), mulai tanggal 3 Januari 2007 sampai 13 maret 2007, frekuensi latihan 3 kali seminggu. Jumlah pertemuan keseluruhan adalah 28 kali. Pertemuan pertama digunakan untukpengarahan, perkenalan, dan pembagian kelompok, 26 kali perlakuan eksperimen, dan satu kali pertemuan terakhir untuk tes keterampilan bermain bulutangkis. 
Penelitian ini melibatkan dua variabel bebas yang dimanipulasi, dua variabel bebas yang dikendalikan (atribut), dan satu variabel terikat. Variabel bebas yang dimanipulasi terdiri dari (a) model pembelajaran dengan pendekatan taktis, dan (b) model pembelajaran dengan pendekatan konvensional. Variabel bebas yang dikendalikan (atribut) adalah kemampuan motorik tinggi dan rendah, sedangkan variabel terikatnya adalah keterampilan bermain bulutangkis. Rancangan penelitian menggunakan desain faktorial $2 \times 2$. Unit-unit eksperimen dikelompokkan ke dalam sel sehingga unit-unit eksperimen relatif homogen.

Agar rancangan penelitian yang dilaksanakan dapat memenuhi persyaratan untuk pengujian hipotesis, dan hasilnya dapat mencerminkan perlakuan yang diberikan, serta dapat digeneralisasikan ke populasi yang ada. Oleh karena itu, dalam penelitian ini dilakukan pengontrolan terhadap validitas internal dan validitas eksternal.

\section{POPULASI DAN SAMPEL}

Populasi penelitian menggunakan populasi terjangkau, yaitu siswa pemula puteri yang berumur di bawah 13 tahun anggota Diklat Bulutangkis FPOK UPI yang belum memiliki keterampilan bermain bulutangkis dan terdaftar pada tahun ajaran 2007. Dari data yang diperoleh terdapat 72 siswa pemula puteri yang berusia antara 10 tahun sampai dengan 13 tahun dan terdaftar pada tahun 2007. Dengan demikian, populasi terjangkau pada penelitian ini berjumlah 72 siswa pemula puteri yang berusia di bawah 13 tahun.
Teknik pengambilan sampel dengan random sampling sederhana. Setelah itu, dilakukan tes kemampuan motorik. Untuk menentukan kategori tinggi atau rendah skor kemampuan motorik, dilakukan dengan cara mengurutkan berdasarkan skor yang diperoleh setiap anak untuk setiap kelompok perlakuan. Selanjutnya, membagi anggota kelompok untuk taraf kemampuan motorik tinggi dan taraf kemampuan motorik rendah berdasarkan persentase, yaitu 27\% untuk batas atas yang mewakili kelompok skor tinggi dan $27 \%$ batas bawah yang mewakili kelompok skor rendah. Didapatkan 20 sampel untuk setiap kelompok perlakuan yang terdiri dari 10 sampel dengan skor kemampuan motorik tinggi dan 10 sampel dengan skor kemampuan motorik rendah. Jumlah tersebut diperoleh dari $27 \%$ batas atas dan $27 \%$ batas bawah yaitu dari setiap 9,72 (diambil 10 orang). Dengan demikian, secara keseluruhan jumlah sampel yang mendapatkan perlakuan sebanyak 40 siswa, yang diambil dari subjek penelitian sebanyak 72 siswa, terbagi empat kelompok perlakuan, yaitu dua kelompok untuk model pembelajaran dengan pendekatan taktis (kemampuan motorik tinggi dan rendah), dan dua kelompok untuk model pembelajaran dengan pendekatan konvensional (kemampuan motorik tinggi dan rendah).

\section{INSTRUMEN PENELITIAN}

Instrumen pengukuran diperlukan untuk memperoleh informasi mengenai kemampuan motorik dan keterampilan bermain bulutangkis model pembelajaran pendekatan taktis dan pendekatan konvensional. Kedua model 
pembelajaran tersebut dijadikan sebagai subjek eksperimen yang akan digunakan terhadap unit eksperimen dalam ruang lingkup desain yang dipilih.

\section{TES KEMAMPUAN MOTORIK}

Kemampuan motoriksecara konseptual didefinisikan sebagai berikut. Kemampuan motorik adalah kapasitas penampilan keterampilan gerak seseorang untuk melakukan berbagai keterampilam motorik dan aktivitas fisik secara keseluruhan. Dari definisi konseptual tersebut, kemampuan motorik akan diukur dengan tes kemampuan motorik yang digunakan untuk anak usia sekolah dasar, yang terdiri dari 7 (tujuh) butir tes, yaitu: (a) melempar pada sasaran atu target; (b) kelentukan togok dan tungkai bagian belakang; (c) melompat jauh ke depan tanpa awalan; (d) telungkup langsung bangun; (e) Push-up pada kursi; (f) keseimbangan statis; dan (g) kelincahan.

\section{TES KETERAMPILAN BERMAIN BULUTANGKIS}

Keterampilan bermain bulutangkis adalah kemampuan seorang pemain bulutangkis dalam menampilkan kemahiran geraknya secara efektif dan efisien dalam permainan bulutangkis yang dapat diamati melalui penampilannya dalam memperagakan keterampilan bermain bulutangkis yang meliputi; dimensi penempatan posisi dan gerakan kaki, serta keterampilan memukul satelkok. Pengetesan dilakukan sebanyak tiga kali. Setiap gerakan dan pukulan satelkok diamati oleh tiga orang juri dan dicatat pada format yang telah disediakan. Pengisian format penilaian dilaku- kan dengan cara memberikan tanda cek (v) pada kolom yang tersedia. Tanda cek tersebut digunakan untuk menentukan seorang pemain melakukan pergerakan dan teknik memukul satelkok dengan baik, cukup baik, atau kurang baik. Urutan gerakan memukul yang dilakukan testee seperti: servis, lob, drive, dropshot, netting, dan smash. Untuk mengukur tingkat keterampilan bermain bulutangkis, ditentukan dengan menjumlahkan nilai (skor) yang diperoleh dari tiga orang juri, dari setiap indikator penilaian untuk setiap pemain. Pengukuran dengan cara tally diharapkan akan memudahkan mengobservasi dalam mengamati penampilan yang diperagakan secara simultan.

\section{TEKNIK ANALISIS DATA}

Data hasil tes keterampilan bermain bulutangkis dianalisis menggunakan teknik analisis varians (ANAVA) untuk desain eksperimen faktorial, kemudian diikuti dengan uji lanjut menggunakan uji Tukey. Sebelum data dianalisis, terlebih dulu dilakukan uji persyaratan, yaitu uji normalitas dan uji homogenitas. Uji normalitas menggunakan uji Liliefors, sedangkan uji homogenitas menggunakan uji Barlett. Untuk semua pengujian yang dilakukan dengan taraf kepercayaan $5 \%(\alpha \dot{\alpha} 0,05)$.

\section{HASIL PENELITIAN}

Pengujian hipotesis penelitian dilakukan dengan analisis varians dua jalan. Selanjutnya, untuk mengetahui perbedaan keterampilan bermain bulutangkis di antara empat kelompok siswa pemula puteri yang diberi perlakuan berbeda dilakukan analisis dengan 
uji Tukey. Hasil analisis data yang dilakukan dengan menggunakan analisis varians dirangkum dan disajikan dalam bentuk Tabel 1 berikut.

Tabel 1: Rangkuman Hasil ANAVA Dua Jalan

\begin{tabular}{lllllll}
\hline $\begin{array}{c}\text { Sumber } \\
\text { Variasi }\end{array}$ & JK & dk & \multicolumn{1}{c}{ KT } & $\begin{array}{c}\text { RK } \\
\text { Fh }=--- \\
\text { RKD }\end{array}$ & $\begin{array}{c}\text { Ft } \alpha 0,05 \\
(1: 36)\end{array}$ & Interpretasi \\
\hline JKA(b) & 3861,225 & 1 & 3861,225 & 86,19 & 4,11 & Signifikan \\
JKA(k) & 308,025 & 1 & 308,025 & 6,88 & 4,11 & Signifikan \\
JKA (bk) & 366,025 & 1 & 366,025 & 8,17 & 4,11 & Signifikan \\
JKD & 1612,700 & 36 & 44,797 & & & \\
Total (R) & 6147,975 & 39 & - & - & - & \\
\hline
\end{tabular}

Berdasarkan hasil penghitungan seperti pada tabel hasil analisis varians dua jalan di atas, dapat dijelaskan sebagai berikut.

\section{MODEL PENDEKATAN TAKTIS DAN MODEL PENDEKATAN KON- VENSIONAL}

Berdasarkan hasil perhitungan analisis varians mengenai perbedaan pengaruh model pembelajaran pendekatan taktis dibandingkan dengan yang menggunakan model pembelajaran pendekatan konvensional terhadap hasil belajar keterampilan bermain bulutangkis, secara keseluruhan terbukti bahwa terdapat perbedaan antarperlakuan model pembelajaran. Dari hasil Analisis Kovarian diperoleh harga $\mathrm{Fh}_{h}$ antarkolom A sebesar 6,88 yang ternyata lebih besar dari $\mathrm{F}_{t}$ sebesar 4,11 pada taraf signifikansi $\alpha=0,05\left(F_{h}=6,88>F_{t}=4,11\right)$ dengan dk pembilang $V_{1}(\mathrm{a}-1)(\mathrm{b}-1)=1$, $\mathrm{dk}$ penyebut $V_{2} \mathrm{ab}(\mathrm{n}-1)=2 \times 2(10-1)=$ 36. Artinya, hipotesis nol $\left(\mathrm{H}_{0}\right)$ yang menyatakan bahwa tidak ada perbedaan keterampilan bermain bulutangkis antara siswa yangmenggunakanmodel pembelajaran pendekatan taktis dan siswa yang menggunakan model pembelajaran pendekatan konvensional, ditolak atau hipotesis penelitian diterima. Dengan kata lain, dapat dinyatakan bahwa terdapat perbedaan hasil belajar keterampilan bermain bulutangkis antara siswa yang menggunakan model pembelajaran pendekatan taktis dengan siswa yang menggunakan model pendekatan konvensional.

Berdasarkan hasil analisis, ternyata hasilbelajar keterampilan bermain bulutangkis siswa yang menggunakan model pembelajaran pendekatan taktis lebih tinggi (baik) daripada yang menggunakan model pembelajaran pendekatan konvensional $\left(\mathrm{X}_{\mathrm{A} 1}=149,05>\mathrm{X}_{\mathrm{A} 2}=\right.$ 143,5). Hal ini berarti hipotesis yang menyatakan bahwa secara keseluruhan terdapat perbedaan hasil belajar keterampilan bermain bulutangkis antara siswa pemula puteri yang menggunakan model pendekatan taktis dengan model pembelajaran pendekatan konvensional telah teruji.

Untuk mengetahui tingkat perbedaan dilakukan uji lanjut dengan menggunakan uji Tukey. Berdasarkan uji Tukey diperoleh harga $q=3,71$ yang le- 
bih besar daripada $\mathrm{q}$ tabel $\left(\mathrm{q}_{\mathrm{t}}\right)=2,86$ atau $\mathrm{q}>\mathrm{q}_{\mathrm{t}}$ pada taraf signifikansi $\alpha=$ 0,05, dengan $\mathrm{dk}$ 2:36 (terdekatnya 40), sehingga $\mathrm{H}_{0}$ ditolak. Dengan demikian, dapat disimpulkan bahwa terdapat perbedaan hasil belajar yang signifikan antara model pembelajaran pendekatan taktis dan model pembelajaran pendekatan konvensional. Dengan kata lain, dapat dinyatakan bahwa model pembelajaran pendekatan taktis memiliki pengaruh lebih tinggi (baik) daripada model pendekatan konvensional terhadap hasil belajar keterampilan bermain bulutangkis siswa pemula puteri.

\section{MODEL PENDEKATAN TAKTIS DAN KONVENSIONAL PADA SIS- WA YANG MEMILIKI KEMAMPU- AN MOTORIK TINGGI}

Berdasarkan hasil perhitungan analisis varians tahap lanjut dengan uji Tukey mengenai perbedaan hasil belajar keterampilan bermain bulutangkis antara siswa yang menggunakan model pembelajaran pendekatan taktis dengan yang menggunakan model pembelajaran pendekatan konvensional pada siswa pemula puteri yang memiliki kemampuan motorik tinggi, secara keseluruhan seperti tampak pada Tabel 1 . Terbukti bahwa siswa yang memiliki kemampuan motorik tinggi, terdapat perbedaan hasil belajar antara siswa yang menggunakan model pembelajaran pendekatan taktis $\left(\mathrm{A}_{1} \mathrm{~B}_{1}\right)$ dan yang menggunakan model pembelajaran pendekatan konvensional $\left(\mathrm{A}_{2} \mathrm{~B}_{1}\right)$. Pada kelompok $A_{1} B_{1}$ dan $A_{2} B_{1}$ harga $q=6,43$ lebih besar daripada $\mathrm{q}_{\mathrm{t}}=3,79$ atau $\mathrm{q}=$ $6,43>q_{t}=3,79$. Dengan demikian, hipotesis nol $\left(\mathrm{H}_{0}\right)$ ditolak. Artinya, hasil be- lajar keterampilan bermain bulutangkis siswa yang memiliki kemampuan motorik tinggi yang mengggunakan model pembelajaran pendekatan taktis lebih tinggi (baik) daripada yang menggunakan model pembelajaran pendekatan konvensional $\left(\overline{\mathrm{X}}_{\mathrm{A} 1 \mathrm{~B} 1}=161,9>\overline{\mathrm{X}}_{\mathrm{A} 2 \mathrm{~B} 1}=\right.$ 150,3). Hal ini berarti hipotesis penelitian yang menyatakan bahwa terdapat perbedaan hasil belajar antara siswa yang menggunakan model pembelajaran pendekatantaktis dengan yang menggunakan model pembelajaran pendekatan konvensional pada siswa pemula puteri yang memiliki kemampuan motorik tinggi telah teruji.

Adapun hasil analisis data penelitian untuk menguji dan membuktikan hipotesis ini, ternyata diperoleh harga rata-rata hasil belajar keterampilan bermain bulutangkis siswa yang memiliki kemampuan motorik tinggi yang menggunakan model pembelajaran pendekatan taktis sebesar $\mathrm{X}_{\mathrm{A} 1 \mathrm{~B} 1}=161,9$ dengan simpangan baku sebesar $(\mathrm{SD})=$ 6,19 dan harga rata-rata hasil belajar keterampilan bermain bulutangkis siswa yang menggunakan model pembelajaran pendekatan konvensional sebesar $\mathrm{X}_{\mathrm{A} 2 \mathrm{~B} 1}=150,3$ dengan simpangan baku sebesar $\mathrm{s}=7,39$. Oleh karena secara keseluruhan pada kedua model pembelajaran tersebut terbukti bahwa hasil belajar keterampilan bermain bulutangkis dengan menggunakan model pembelajaran pendekatan taktis lebih tinggi (baik) daripada hasil belajar dengan menggunakan model pembelajaran pendekatan konvensional. 
MODEL PENDEKATAN TAKTIS DAN KONVENSIONAL PADA SISWA YANG MEMILIKI KEMAMPUAN MOTORIK RENDAH

Berdasarkan hasil perhitungan analisis varians tahap lanjut dengan menggunakan uji Tukey mengenai perbedaan keterampilan bermain bulutangkis siswa pemula puteri yang memiliki kemampuan motorik rendah antara yang mengikuti pembelajaran pendekatan taktis dan yang mengikuti model pembelajaran pendekatan konvensional, secara keseluruhan seperti tampak pada Tabel 1. Terbukti bahwa tidak terdapat perbedaan yang signifikan bagi yang memiliki kemampuan motorik rendah antara yang mengikuti model pembelajaran pendekatan taktis $\left(\mathrm{A}_{1} \mathrm{~B}_{2}\right)$ dan yang mengikuti model pendekatan konvensional $\left(\mathrm{A}_{2} \mathrm{~B}_{2}\right)$. Pada kelompok $\mathrm{A}_{1} \mathrm{~B}_{2}$ dan $A_{2} B_{2}$ harga $q=-0,24$ lebih kecil daripada $\mathrm{q}_{\mathrm{t}}=3,79$ atau $\mathrm{q}=-0,24<\mathrm{q}_{\mathrm{t}}=3,79$, berarti hipotesis nol $\left(\mathrm{H}_{0}\right)$ diterima. Artinya, hasil keterampilan bermain bulutangkis siswa pemula puteri yang memiliki kemampuan motorik rendah yang menggunakan model pendekatan taktis tidak lebih baik daripada yang menggunakan model pendekatan konvensional ( $\left.\overline{\mathrm{X}}_{\mathrm{A} 1 \mathrm{~B} 2}=136,2<\overline{\mathrm{X}}_{\mathrm{A} 2 \mathrm{~B} 2}=136,7\right)$. Hal ini berarti hipotesis yang menyatakan bahwa terdapat perbedaan hasil belajar keterampilan bermain bulutangkis antara siswa yang menggunakan model pembelajaran pendekatan taktis dengan yang menggunakan pendekatan konvensional pada siswa pemula puteri yang memiliki kemampuan motorik rendah tidak terbukti.

Hasil analisis data penelitian untuk menguji dan membuktikan hipotesis ini, ternyata diperoleh harga rata-rata hasil belajar keterampilan bermain bulutangkis siswa yang memiliki kemampuan motorik rendah menggunakan model pembelajaran pendekatan taktis sebesar $\mathrm{X}_{\mathrm{A} 1 \mathrm{~B} 2}=136,2$ dengan simpangan baku sebesar $\mathrm{s}=5,33$ dan harga ratarata keterampilan bermain bulutangkis siswa yang menggunakan model pembelajaran pendekatan konvensional sebesar $\mathrm{X}_{\mathrm{A2} \text { B2 }}=136,7$ dengan simpangan baku sebesar $s=7,6$. Oleh karena bagi kelompok siswa yang memiliki kemampuan motorik rendah pada kedua model pembelajaran tersebut tidak berbeda secara signifikan.

\section{INTERAKSI ANTARA MODEL PEM- BELAJARAN DAN KEMAMPUAN MOTORIK}

Berdasarkan hasil perhitungan analisis varians tahap lanjut dengan taraf sigifikansi $\alpha=0,05$, diperoleh harga $\mathrm{Fh}_{\mathrm{h}}$ sebesar 8,17 yang ternyata lebih besar dari $F_{t}$ sebesar 4,11 pada taraf signifikansi $\alpha=0,05,\left(F_{h}=8,17>F_{t}=4,11\right)$ dengan dk pembilang $V_{1}(\mathrm{a}-1)(\mathrm{b}-1)=1$, dk penyebut $V_{2}$ ab $(\mathrm{n}-1)=2 \times 2(10-1)=36$. Artinya, hipotesis nol $\left(\mathrm{H}_{0}\right)$ yang menyatakan bahwa tidak ada interaksi antara model pembelajaran dan kemampuan motorik terhadap hasil belajar keterampilan bermain bulutangkis siswa pemula puteri, ditolak atau hipotesis penelitian diterima. Dengan kata lain, dapat dinyatakan bahwa terdapat interaksi antara model pembelajaran dan kemampuan motorik terhadap hasil belajar keterampilan bermain bulutangkis siswa pemula puteri. Untuk lebih jelasnya interaksi tersebut dapat dilihat melalui gambar berikut. 


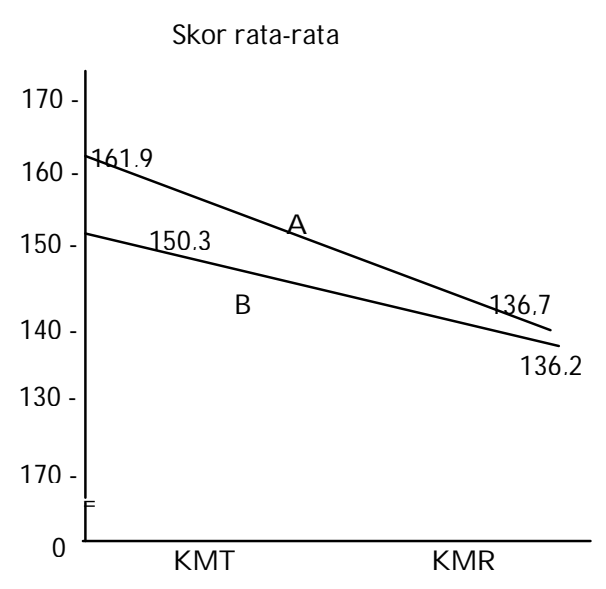

Gambar 1: Interaksi antara Model

Pembelajaran dengan Kemampuan Motorik terhadap Hasil Belajar Keterampilan Bermain Bulutangkis

\section{Keterangan:}

A : Model Pembelajaran Pendekatan Taktis

B : Model Pembelajaran Pendekatan Konvensional

KMT: Kemampuan Motorik Tinggi

KMR: Kemampuan Motorik Rendah

Dari data hasil penelitian dapat dilihat bahwa sekor rata-rata hasil belajar keterampilan bermain bulutangkis yang menggunakan model pembelajaran pendekatan taktis adalah sebesar 161,9 untuk kelompok siswa yang memiliki kemampuan motorik tinggi dan 136,2 untuk kelompok siswa yang memiliki kemampuan motorik rendah. Kemudian, skor rata-rata keterampilan bermain bulutangkis siswa yang mengikuti model pembelajaran pendekatan konvensional adalah sebesar 150,3 untuk kelompok siswa yang memiliki kemampuan motorik tinggi dan 136,7 untuk kelompok siswa yang memiliki kemampuan motorik rendah. Dengan demikian, dapat disimpulkan bahwa terdapat interaksi antara model pembelajaran dan kemam- puan motorik terhadap hasil belajar keterampilan bermain bulutangkis siswa pemula puteri.

\section{PEMBAHASAN HASIL PENELITIAN MODEL PEMBELAJARAN PENDE- KATAN TAKTIS DAN KONVENSIO- NAL}

Berdasarkan hasil analisis data penelitian, diperoleh hasil bahwa hipotesis penelitian yang menyatakan bahwa terdapat perbedaan hasil belajar antara siswa yang menggunakan model pembelajaran pendekatan taktis dan pendekatan konvensional diterima. Hal itu berarti bahwa model pembelajaran pendekatan taktis ternyata lebih tinggi dalam pencapaian tujuan pembelajaran keterampilan bermain bulutangkis siswa pemula puteri bila dibandingkan dengan yang menggunakan model pendekatan konvensional.

Hasil analisis data tersebut ternyata sesuai dengan teori yang mengemukakan bahwa model pendekatan taktis diarahkan pada upaya untuk meningkatkan keterampilan bermain dengan memadukan antara keterampilan dengan pemahaman bermain, serta mendorong agar siswa dapat menghargai nilai-nilai keterampilan dalam konteks permainan. Model pembelajaran pendekatan taktis memiliki keunggulan di antaranya bentuk pembelajaran keterampilan bermain bulutangkis yang disajikan dengan mengutamakan pemahaman bermain dan pelaksanaannya mirip atau menyerupai dengan situasi permainan bulutangkis yang sesungguhnya. Selain itu, situasi lingkungan pembelajaran selalu berubah-ubah, sehingga kemampuan siswa dalam mengantisipasi terhadap satelkok dan arah pukulan sudah 
terbiasa. Model pembelajaran pendekatan taktis lebih menekankan kepada fungsi dari keterampilan bermain bulutangkis dalam situasi permainan. Artinya, produktivitas dalam melakukan keterampilan bermain lebih diutamakan daripada proses melakukan teknik. Dengan lebih menekankan pada fungsi keterampilan bermain, maka siswa dituntut selalu kreatif dan peka terhadap datangnya satelkok. Oleh karena itu, peluang siswa untuk memiliki pemahaman terhadap permainan bulutangkis lebih besar, dan pengembangan dalam aspek kognitif, afektif, dan psikomotor.

Pada model pembelajaran pendekatan konvensional, bentuk latihan keterampilan bermain bulutangkis yang disajikan tidak menyerupai dengan situasi permainan bulutangkis yang sesungguhnya. Selain itu, situasi lingkungan belajar relatif stabil, siswa tidak perlu melakukan antisipasi terhadap satelkok dan arah pukulan. Sebab satelkok yang diumpankan guru, arah dan tempat jatuhnya sudah diketahui dan di tempat yang tetap. Situasi pembelajaran tersebut berbeda dengan situasi permainan bulutangkis yang sebenarnya, sehingga akan menyulitkan siswa dalam penguasaan keterampilan bermain bulutangkis.

Pada model pembelajaran pendekatan konvensional lebih menekankan kepada bentuk dari teknik dasar permainan bulutangkis. Artinya, proses gerakan teknik bermain bulutangkis lebih diutamakan daripada fungsi bermain bulutangkis. Dengan lebih menekankan pada bentuk teknik, maka latihan yang dilakukan siswa menjadi monoton, tidak memperhitungkan kreativitas dan kurang peka terhadap datangnya satelkok. Namun dengan bentuk latihan pada model konvensional lebih cocok untuk terapi kesalahan gerak teknik. Hal itu disebabkan oleh cara penyajian materi yang melalui tahapan-tahapan dari seluruh rangkaian teknik bulutangkis.

\section{HASIL BELAJAR KETERAMPILAN BERMAIN BULUTANGKIS PADA EMPAT KELOMPOK SISWA YANG MENDAPATKAN PERLAKUAN BER- BEDA}

Hasil penelitian menemukan adanya keterkaitan antara model pembelajaran dan kemampuan motorik serta pengaruhnya terhadap hasil belajar keterampilan bulutangkis siswa pemula puteri. Siswa yang memiliki kemampuan motorik tinggi yang menggunakan model pembelajaran pendekatan taktis memperoleh hasil keterampilanbermain bulutangkis yang lebih tinggi daripada yang menggunakan model pendekatan konvensional. Namun, sebaliknya bagi siswa yang memiliki kemampuan motorik rendah, penggunaan model pembelajaran dengan model pendekatan taktis maupun dengan model pendekatan konvensional, hasil belajarnya tidak menunjukkan adanya perbedaan pengaruh yang signifikan. Hal ini menunjukkanbahwa efektivitas suatu model pembelajaran berkaitan erat dengan kemampuan motorik dan karakteristik siswa.

Beberapahalyang kemungkinan menyebabkan tidak terujinya hipotesis ke tiga ini di antaranya sebagai berikut. Pertama, program pembelajaran yang diberikan kepada siswa yang memiliki kemampuan motorik rendah baik melalui pendekatan taktis maupun kon- 
vensional yang diberikan secara merata dan sebanding dengan siswa lainnya, tidak dapat diterima secara utuh oleh para siswa, karena siswa tersebut lebih lambat mempelajari keterampilan gerak yang baru, sehingga hasil belajar yang diperolehnya tidak terdapat perbedaan yang berarti. Kedua, keterbatasan alat ukur yang digunakan dalam penelitian, penggunaan instrumen melalui penilaian keterampilan bermain bulutangkis yang dilakukan melalui pengamatan, ada kemungkinan pengamat melakukan kesalahan (persepsi) yang berbeda karena keterbatasan dalam ketelitian dan kewaspadaan. Hal ini dapat mengakibatkan terjadinya bias dalam penilaian. Ketiga, permainan bulutangkis merupakan permainan yang menarik dan banyak dinikmati semua kalangan, sehingga ketertarikan untuk memainkan permainan sangat besar yang dapat mengakibatkan adanya peningkatan usaha pemain untuk bermain bulutangkis dan kurang menghiraukan teknik dasar yang dipelajarinya.

\section{INTERAKSI ANTARA MODEL PEM- BELAJARAN DAN KEMAMPUAN MOTORIK TERHADAP KETERAM- PILAN BERMAIN BULUTANGKIS}

Dari hasil pengujian hipotesis juga ditemukan adanya interaksi antara model pembelajaran dan kemampuan motorik terhadap hasil belajar keterampilan bermain bulutangkis siswa pemula puteri. Interaksi keduanya terlihat dari adanya perbedaan pengaruh perlakuan terhadap keterampilan bermain bulutangkis pada kedua tingkat kemam-puan motorik siswa pemula puteri. Dengan kata lain, penggunaan model pembelajaran hendaknya dilakukan dengan terlebih dahulu melihat kemampuan motoriknya. Penggunaan model pendekatan taktis ternyata lebih efektif apabila digunakan untuk memberikan pembelajaran kepada siswa yang memiliki kemampuan motorik tinggi. Pada siswa yang memiliki kemampuan motorik rendah nampaknya model pembelajaran pendekatan konvensional lebih efektif apabila dibandingkan dengan pendekatan taktis walaupun secara statistika tidak signifikan.

\section{KESIMPULAN}

Berdasarkan data yang diperoleh, hasil pengujian hipotesis, dan pembahasan hasil penelitian dapat disimpulkan sebagai berikut.

$>$ Secara keseluruhan terdapat perbedaan hasil belajar keterampilan bermain bulutangkis antara siswa pemula puteri yang menggunakan model pendekatan taktis dengan yang menggunakan model pendekatan konvensional. Hasil belajar keterampilan bermain bulutangkis siswa pemula puteri yang menggunakan pendekatan taktis lebih baik daripada yang menggunakan pendekatan konvensional pada siswa pemula puteri.

Terdapat perbedaan hasil belajar keterampilan bermain bulutangkis antara siswa yang menggunakan model pendekatantaktis dengan yang menggunakan model pendekatan konvensional pada siswa yang memiliki kemampuan motorik tinggi, yang dalam hal ini hasil belajar keterampilan bermain bulutangkis dengan menggunakan pendekatan taktis lebih baik daripada pendekatan konvensional 
pada siswa pemula puteri yang memiliki kemampuan motorik tinggi.

Bagi siswa yang memiliki kemampuan motorik rendah, hasil belajar keterampilan bermain bulutangkis siswa pemula puteri yang menggunakan model pembelajaran pendekatan taktis tidak berbeda secara signifikan dibandingkan dengan siswa yang menggunakan model pendekatan konvensional.

Terdapat interaksi yang positif antara model pembelajaran dan kemampuan motorik terhadap hasil belajar keterampilan bermain bulutangkis siswa pemula puteri pada Diklat Bulutangkis FPOK UPI.

\section{UCAPAN TERIMA KASIH}

Terima kasih penulis ucapkan kepada Redaktur yang telah memberikan inputuntukperbaikan artikel ini. Terima kasih juga penulis ucapkan kepada segenap pengurus Jurnal Cakrawala Pendidikan sehingga artikel ini dapat diterbitkan dalam mimbar ilmiah ini.

\section{DAFTAR PUSTAKA}

Anderson, J. R. 1995. Learning and Memory. NewYork: John Willey \& Son Inc.

Ballou, Ralph B. 1998. Badminton for Beginners, $2^{\text {nd }}$ ed. Colorado: Morton Publishing Co.

Burden, P. R and Byrd D. M. 1999. Methods for Effective Teaching. Boston: Allyn and Bacon.
Davis, Pat. 1998. Play the Game Badminton. London: A Ward Lock Book.

Djide, Tahir, et. al. (t. t). Pedoman Praktis Bermain Bulutangkis. Jakarta: PB PBSI.

Eggen Paul D., Donald P. Kaushack, Robert J. Harder. 1979. Strategies for Teachers: Information Prosessing Models in the Classroom. Englewood Cliffts, N. J: Prentice-Hall, Inc.

Ferguson, George A. 1981. Statistical Analysis in Psychology and Education, $5^{\text {th }}$ ed. Auckland: McGrawHill Book Company.

Fischman, M. G, and Oxendine, J. B. 1993. Motor Skill Learning for Effective Coaching and Performance. In Williams, J.M. Applied Sport Psychology, Personal Growth to Peak Performance. London: Mayfield Publishing Company.

Grice, Tony. 1994. Badminton for the College Student, $4^{\text {th }}$ ed. Boston, Massachusetts: American Press.

Griffin, Linda L., Mitchell, Steven A., Oslin, Judith L. 1997. Teaching Sport Concepts and Skills a Tactical Games Approach. Cahmpaign, Illinois: Human Kinetics.

Jian, Han. 2000. Basic Skills of Badminton. Petaling Jaya, Malaysia: Percetakan Solai Sdn Bhd. 8, Jalan 21346050 Petaling Jaya Selangor, Malaysia. 
Kirkendal, Don R., Guber, Joseph J. and Johnson, Robert E. 1980. Measurement and Evaluation for Physical Educators. Iowa: Wm.C. Brown Company Publishers.

Menegpora Republik Indonesia. 2005. Undang-Undang Republik Indonesia Nomor 3 Tahun 2005, tentang Sistem Keolahragaan Nasional. Jakarta: Kementrian Negara Pemuda dan Olahraga.

Mitchell, Stephen A. 1996. “Tactical Approach to Teaching Games: Improving Invansion Games Performance". JOPERD. Volume 67 Number 2. Reston: AAHPERD.

Oslin, Judith L. 1996. "Tactical Approach to Teaching Games". JOPERD. Volume 67. Number 1. Reston: AAHPERD,

Oxendine, Joseph B. 1968. Psychology of Motor Learning. New York: Appleton-Century - Crots.

Schmidt, Richard A. 1991. Motor Learning $\mathcal{E}$ Performance. Illinois: Human Kinetics Books. 1998. Motor Control and Learning: A Behavior Emphasis. Champaign, Illinois: Human Kinetics Publishers Inc.

Seidel, Baverly L. et. al. 1975. Sport Skills. Iowa: Wm. C. Brown Company Publisher.
Singer, Robert N. 1980. Motor Learning and Human Performance: An Aplication to Motor Skills and Movement Behaviors. $3^{\text {rd }}$ ed. New York, London: Macmillan Publishing Co. Inc.

Singer, Robert N, and Walter, Dick. 1980. Teaching Physical Education: ASystem Approach. Boston: Houghton Miffin Company.

Sudjana. 1992. Metoda Statistika. Bandung: Penerbit Tarsito. . 1994. Design dan Analisis Eksperimen. Bandung: Tarsito.

Tarigan, Beltasar. 1998. Keberhasilan Model Pembelajaran BM 77 dan Konvensional terhadap Keterampilan Bermain Bulutangkis Anak Usia Dini. Jakarta: PPs IKIP Jakarta.

Wall, Jeniffer and Nancy, Murray. 1994. Children and Movement. Iowa: Wm. C. Brown and Benchmark.

Wattanasin, Charuen. 2000. Badminton a Simple Way, Badminton Booklet. London: The IBF. 